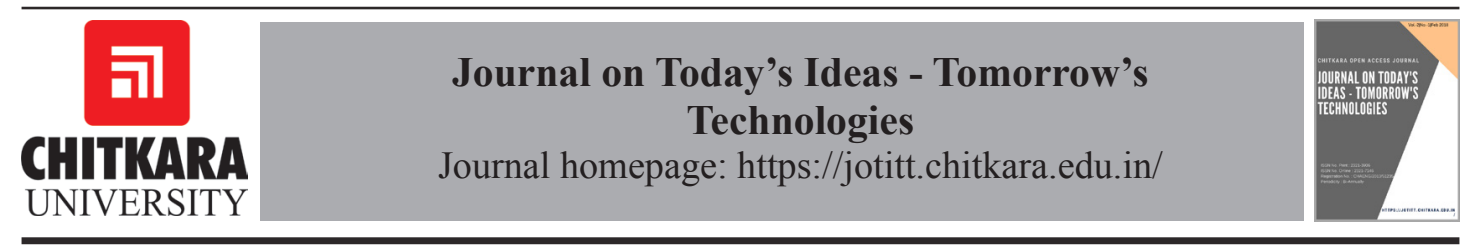

\title{
Exploring Electronic Payment System Acceptibility Determinants: A Consumer Outlook
}

\author{
Akanksha Upadhyaya*, Bhajneet Kaur \\ Rukmini Devi Institute of Advanced Studies, Delhi, India. \\ *Email: akanksha.bhardwaj@rdias.ac.in
}

ARTICLE INFORMATION

DOI: $10.15415 /$ jotitt.2018.61002

Keywords: Electronic payment

system, e-commerce, online

transactions, exploratory factor

analysis, $\mathrm{B} 2 \mathrm{~B}, \mathrm{~B} 2 \mathrm{C}, \mathrm{C} 2 \mathrm{C}$, e-business

\begin{abstract}
The aim of this research paper is to explore the electronic payment system (EPS) acceptability determinants, from the consumer perspective. Exploratory factor analysis has been used to explore the factors based on different statements. The study has been conducted in North-West region of Delhi. Data has been collected from male-female of different age groups by using the questionnaire tool of data collection. For extraction of factors Principal component analyses and Varimax with Kaiser Normalization rotation method was used. The rotated component matrix shows best fitting of items to form a factor. As per the convergence of items, 4 factors were extracted and named. These factors are security concern, Knowledge, awareness and acceptability \& convenience which are contributing for acceptability of electronic payment system among the consumers.
\end{abstract}

\section{Introduction}

Electronic payment system (EPS) is a way to transact online for the goods and services availed. EPS has gained popularity in recent years due to widespread of various applications dealing online for goods and services. Ranging from $\mathrm{B} 2 \mathrm{~B}$, $\mathrm{B} 2 \mathrm{C}, \mathrm{C} 2 \mathrm{C}$ e- commerce models, digital wallets, EPS has its own benefits in terms of facilitating electronic payments for any kind of payments and transactions. Business to Business (B2B) model basically involves wholesaler and producer as an entity to deal with goods and services and also for the electronic transactions. In Business to
Consumer $(\mathrm{B} 2 \mathrm{C})$ model is basically retail electronic commerce trade in which associated entities are business and the end customer. The transactions are done between these two entities. Whereas, in case of Consumer to Consumer $\left(\mathrm{C}_{2} \mathrm{C}\right)$ model transactions are done between two Consumers. Product deals and electronic transactions are performed between these two entities using third party online platform. Digital wallets have its own advantages in terms of transacting electronically for any products and services. These wallets securely store the payment information and e-cash of a user. Using a login id and password the user can transact online and purchases can be 
done easily and quickly. Therefore, in order to outline the past study conducted in this direction and thereby finding the objective of study, the introduction section is divided into two parts: Background of study and purpose of study. First section includes various studies that have been conducted for identification of contributing factors for widespread acceptability of EPS among consumers and next section deals with the objective of study that has been defined after conducting the review of literature.

\section{Background of study}

In recent time electronic payment (EPS) has been given attention due to the importance and relevancy of E-commerce. There are various determinants or factors which are influencing the acceptability of EPS i.e. usefulness, trust, ease of use, security, cost, benefit, awareness, IT skills, flexibility and convenience [1]. EPS has been classified into 5 categories i.e. Electronic cash is the payment method which needs specific id number with the amount of money, the cash transfers through the digital payment system with various communication channels [2], Pre-paid cards can be used in stores or through online transactions, generates from specific value by specific trader/ merchant, given as gift cards, Credit cards and debit cards are plastic payment cards. Credit cards has high complex payment structure and provide secure interface to its customers and debit cards are also secure medium to purchase the goods or services both online and offline. The payment is automatically deducted from the customer's account and it is one of the frequent using methods of e-payment [2]. Electronic cheque is the least frequent method of e-payment as compared to other payment methods. Security is one of the factor found as an important factor affects accessibility of e-payment system by the customer point of view, with the security determinant mainly four factors have been found as per the past study i.e. transaction procedure, security statements, technical protection \& individual past experience [2]. F. Arne et al. [3] identified the factor ease of use or convenience which is confirmed factor in the multitude studies using Technology Acceptance Model (TAM) model. The TAM model is basically based on Information theory and defines that how the users come forward to accept the use of technology. Ease of use has significance relationship with the online payment system. Two very important factors which have been influenced to the accessibility of user for the use of e-payment system are recognition in benefits and usability of the system.

\section{Purpose of study}

The main aim to conduct this study is to identify the factors causing Electronic payment system acceptability among the consumers. The study is exploratory in nature and considered the reasons shown in past study for development of factors. The main objective of the study is "to identify the factors which are causing acceptability of Electronic payment system by consumers for transacting electronically".

\section{Research methodology}

\subsection{Sample E data collection}

The study was conducted among 134 respondents from the public of Northwest region of Delhi. Convenience sampling method was used for data collection. The targeted population was 300 individuals. Total 134 responses 
were correctly received, after rigorous checking of response collected. The response rate was $44.6 \%$, which is considered to be good for conducting the study, as mentioned by Roscoe (1975). One of the studies also mentioned that to avoid sample biasness the response rate must be greater than 30\%, Sekaran (2003). Therefore 134 responses are sufficient to conduct the exploratory factor analysis.

\subsection{Instrument}

The survey conducted was offline in nature and questionnaire was built on 5-point likert scale using MS-Word 2010. The first part of the questionnaire consists of demographics such as Age, Gender and weekly frequency of transacting online. The questionnaire was pre-tested by showing it to the some of the respondents who uses Electronic payment systems very frequently as well as infrequently. The content validity was validated by showing the questionnaire to the experts such as bank employees and some of the website developers. The main objective to show the questionnaire is to ensure the sufficiency of coverage of items under study. Thereafter the statements were redefined as per their suggestions and tested for reliability. Cronbach alpha is popularly used for reliability of the statements and it is found to be greater than 0.7 (Nunnally, 1978). Therefore, it reveals the internal consistency of the items. The value of Cronbach alpha was analyzed over 22 items and 134 respondents.

\section{Data analysis and interpretation}

\subsection{Demographics}

Table 1 shows demographics of respondents. Approximately 58\% respondents were male and $48 \%$ were female. Furthermore, the majority of respondents lays in the age group of $26-40(38 \%)$ and the age group less than $25(26 \%)$. The demographics related to frequency of transacting electronically also revealed that most of the respondents i.e. $42 \%$ perform $2-5$ number of electronic transactions in a week followed by $33 \%$ of respondents using 5-10 electronic transaction weekly and it is least for more than 10 transactions weekly.

Table 1: Demographics of respondents

\begin{tabular}{|c|l|c|}
\hline S. No. & \multicolumn{1}{|c|}{ Respondent's Characteristics } & Percentage (\%) \\
\hline I & Sex & 58 \\
\hline & Male & 42 \\
\hline & Female & \\
\hline II & Age Group & 26 \\
\hline & Less than 25 & 38 \\
\hline & $26-40$ & 17 \\
\hline & $41-55$ & 19 \\
\hline & More than 55 & \\
\hline III & No. electronic transactions (in weeks) & \\
\hline
\end{tabular}




\begin{tabular}{|l|l|c|}
\hline & Less than 1 & 16 \\
\hline & $2-5$ & 42 \\
\hline & $5-10$ & 33 \\
\hline & More than 10 & 9 \\
\hline
\end{tabular}

\section{Exploratory factor analysis}

Exploratory Factor Analysis using Principal Component Analyses and Varimax rotation was used to explore and identify the factors that cause acceptability of Electronic payment system among the consumers. The Exploratory factor analyses were implemented using IBM SPSS statistics 21 tool.

\section{Measuring sample adequacy}

KMO and Bartlett's test was used to measure the sample adequacy. It is suggested that KMO value must be greater than .50 and p-value must be less than .05 for Bartlett's test. To check the appropriateness of factor analysis the KMO and Bartlett's test was used. KMOBartlett test is used for sample adequacy because KMO shows the variance proportion of the variables which yields the distinct factors and reliable factors while Bartlett's test defines the presence of correlation among the variables therefore; it is measured for the p-value less than .005. Hence Table 2 shows that items are reliable to continue for factor extraction.

Table 2: KMO and Bartlett's test

\begin{tabular}{|l|l|r|}
\hline Kaiser-Meyer-Olkin Measure of Sampling Adequacy. & .753 \\
\hline \multirow{3}{*}{ Bartlett's Test of Sphericity } & Approx. Chi-Square & 969.017 \\
\cline { 2 - 3 } & $\mathrm{df}$ & 153 \\
\cline { 2 - 3 } & Sig. & .000 \\
\hline
\end{tabular}

\section{Total variance explained}

Table 3 shows that total 4 factors can be extracted during exploratory study because 22 items together explains the total variance of
$63.27 \%$ and having Eigen value greater than 1. The total variance more than $60 \%$ accounted to be a good value for factor extraction.

Table 3: Total variance explained and Eigen value greater than 1

\begin{tabular}{|c|c|c|c|c|}
\hline \multirow[t]{2}{*}{ Component } & \multirow{2}{*}{$\begin{array}{c}\text { Initial Eigen } \\
\text { value }\end{array}$} & \multicolumn{3}{|c|}{ Rotation Sums of Squared Loadings } \\
\hline & & Total & \% of Variance & Cumulative \% \\
\hline 1 & 3.930 & 3.867 & 21.484 & 21.484 \\
\hline 2 & 2.734 & 2.589 & 14.386 & 35.870 \\
\hline 3 & 2.553 & 2.566 & 14.258 & 50.128 \\
\hline 4 & 2.166 & 2.360 & 13.109 & 63.237 \\
\hline
\end{tabular}




\section{Principal component analyses}

For extraction of factors Principal component analyses and Varimax with Kaiser Normalization rotation method was used. The rotated component matrix shows best fitting of items to form a factor. All the statements showing the value greater than 5 hence these items are contributing and converging to make a factor. As per the convergence of items into a factor 4 factors were extracted and named. These factors are security concern, Knowledge, awareness and acceptability \& convenience. Table 4 shows the observed results.

Table 4: Rotated component matrix for factor extraction

\begin{tabular}{|c|c|c|c|c|}
\hline & \multicolumn{4}{|c|}{ Component } \\
\hline & $\begin{array}{c}\text { security } \\
\text { concern } \\
\text { and }\end{array}$ & $\begin{array}{l}\text { Knowl- } \\
\text { edge }\end{array}$ & $\begin{array}{c}\text { Aware- } \\
\text { ness }\end{array}$ & $\begin{array}{c}\text { accept- } \\
\text { ability \& } \\
\text { conve- } \\
\text { nience }\end{array}$ \\
\hline $\begin{array}{l}\text { Authenticating each individual prior to transaction is } \\
\text { one of the secure ways of doing payment. }\end{array}$ & .851 & & & \\
\hline $\begin{array}{l}\text { Acknowledgement about transaction to any individual } \\
\text { is one of the secure transactions. }\end{array}$ & .811 & & & \\
\hline $\begin{array}{l}\text { Each EPS provides privacy policy that makes my trans- } \\
\text { action more technically protected. }\end{array}$ & .807 & & & \\
\hline $\begin{array}{l}\text { Each transaction in EPS is traceable, which makes the } \\
\text { EPS more strong and reliable. }\end{array}$ & .803 & & & \\
\hline $\begin{array}{l}\text { Personal past experience related to secure transaction } \\
\text { through EPS makes me willing to use EPS. }\end{array}$ & .764 & & & \\
\hline $\begin{array}{l}\text { A secure transaction enhances my confidence to plastic } \\
\text { money (cards) on EPS. }\end{array}$ & .750 & & & \\
\hline $\begin{array}{l}\text { I feel I have sufficient understanding to learn the fea- } \\
\text { tures provided by EPS. }\end{array}$ & & .827 & & \\
\hline I have technology related skill set. & & .809 & & \\
\hline I have an sufficient experience of using EPS. & & .764 & & \\
\hline $\begin{array}{l}\text { I am very much familiar with various types of electron- } \\
\text { ic payment services. }\end{array}$ & & .763 & & \\
\hline $\begin{array}{l}\text { I am well informed about various E-payment systems } \\
\text { offered. }\end{array}$ & & & .794 & \\
\hline I take interest in learning new EPS. & & & .756 & \\
\hline
\end{tabular}

ISSN No.: 2321-3906 (Print) ISSN No.: 2321-7146 (Online) Registration No.: CHAENG/2013/51235 Periodicity: Bi-Annually 


\begin{tabular}{|c|c|c|}
\hline Various advertisements update me about new EPS. & .691 & \\
\hline I feel EPS are easy to understand and use. & .667 & \\
\hline $\begin{array}{l}\text { I used to watch carefully advertisement and any promo- } \\
\text { tional dimensions. }\end{array}$ & .640 & \\
\hline $\begin{array}{l}\text { Various e-services provided in terms of POS, NEFT, } \\
\text { RTGS etc. help me in transactions. }\end{array}$ & & .877 \\
\hline Eps provides variety of payment modes for ease of use. & & .866 \\
\hline EPS provides services anytime and anywhere. & & .865 \\
\hline
\end{tabular}

\section{Conclusion}

The study explored the factors which are causing acceptability of Electronic payment system among the consumers based on 22 statements. These statements were analyzed using exploratory factor analysis using Principal component analysis and Varimax rotation. The statements prior to exploratory factor analyses were tested for validity and reliability. The implementation of exploratory factor analyses on 22 items revealed that there are 4 major factors i.e. security concern, Knowledge, awareness and acceptability \& convenience, which are contributing for acceptability of electronic payment system among the consumers.

\section{Limitation of study}

The study has revealed the major factors and gone through all the necessary process for identification of factors, but still it has some limitations that can be recovered by refining the analysis.

i. For exploratory study the sample size was adequate but the number can be increased for further refinement of analysis. ii. The statement under each factor shows good reliability but these factors can be confirmed in the extended study.

iii. The results cannot be generalized for other geographical areas.

iv. During literature review various other reasons were also found for acceptability of electronic payment system but during the analysis those reasons did not converged to form a factor, hence not considered.

v. As per the common terrain of TAM standard only the EPS acceptability dimension of customer management as a Horizontal business function was considered. Full-fledged customer management is not taken into consideration.

\section{Future scope}

The limitation of study gives the directions to the researchers for identification of other factors as well as establishment of explored factors through this study. Furthermore, the study can be refined and generalized for other geographic areas.

\section{References}

[1] M. A. Kabir, S. Z. Saidin and A. Ahmi, "Analysis of factors that influence 
electronic payment adoption”, Journal of Engineering and Applied Sciences, vol. 12, pp. 6560-6568, 2017.

[2] E. Oney, G. G. Oksuzoglu and H. W. Rizvi, "The determinants of electronic payment systems usage from consumers' perspective”, Economic Research - Ekonomska Istraživanja, vol. 30, no. 1, pp. 394-415, 2017.

[3] H. Treiblmaier, A. Pinterits and A.Floh, "Success factors of internet payment systems", International Journal of Electronic Business, vol. 6, no. 4, pp. 369-385, 2008. 